\title{
Alteration of the Adrenal Antioxidant Defense System During Aging in Rats
}

Salman Azhar, Luchuan Cao, and Eve Reaven

Geriatric Research, Education and Clinical Center, Veterans Affairs, Palo Alto Health Care System, and the Department of Medicine, Stanford University School of Medicine, Palo Alto, California 94304

\begin{abstract}
The goal of this study was to determine to what extent aging affects the antioxidant defense system of the rat adrenal and to evaluate the impact of any change in this system on the recognized age-related decline in steroidogenic capacity of adrenocortical cells. The studies were conducted on young (2-5 mo) and aging (12-27 mo) Sprague-Dawley rats and involved procedures measuring steroidogenesis; oxidative damage to tissue; non enzymatic antioxidants such as vitamin C, E, and glutathione; and tissue antioxidant enzyme (Mn and CuZn superoxide dismutases, catalase, and glutathione peroxidase) activity and expression (mRNA, protein mass, and location). Some measurements were made also on rats maintained on vitamin $\mathbf{E}$-deficient diets. The data show that adrenals from young animals are especially well protected against oxidative events; i.e., these adrenals show the least endogenous lipid peroxidation and the highest level of resistance to prooxidant-induced damage (of various tissues measured) and show exceedingly high levels of tissue antioxidants. Aging, on the other hand, results in oxidative changes in adrenal tissue that are generally linked in time to a reduction in efficiency of the normally protective antioxidant defense system and to the decline in corticosterone production. We speculate that these events are causally related, i.e., that the age-related reduction in oxidative mechanisms in adrenal tissues leads to oxidative damage of membrane or cytosolic factors important to cholesterol transport, and, as a consequence of this damage, cholesterol cannot reach appropriate mitochondrial cholesterol side chain cleavage sites, and corticosterone production fails. ( $J$. Clin. Invest. 1995. 96:1414-1424.) Key words: lipid peroxidation • lipid hydroperoxides • antioxidant enzymes • nonenzymatic antioxidants $\cdot$ steroidogenesis
\end{abstract}

\section{Introduction}

Studies from this laboratory (1-5) and of others (6-12) have shown that aging in rats is associated with a decreased steroidogenic response; i.e., when specifically challenged in vitro, isolated adrenocortical cells (or Leydig cells) of 18-24-mo-old rats (of several different strains) produce and secrete significantly less hormone in response to maximal trophic hormone stimulation than do cells from young (2-mo-old) or mature (5-6-mo-old) rats. Although the mechanism behind this aging

Address correspondence to Salman Azhar, Ph.D., Veterans Affairs, Palo Alto Health Care System (GRECC/182-B), 3801 Miranda Avenue, Palo Alto, CA 94304. Phone: 415-858-3933; FAX: 415-855-9437.

Received for publication 17 January 1995 and accepted in revised form 2 May 1995

The Journal of Clinical Investigation, Inc.

Volume 96, September 1995, 1414-1424 defect is not understood, a number of observations $(2,4,11$ 13) suggest that it may involve inadequate processing of intracellular cholesterol or inefficient transport of cholesterol to mitochondrial side chain cleavage sites for the initial steps in steroidogenesis. This occurs despite the fact that internalization of lipoprotein cholesteryl ester is quite normal $(5,14)$ and intracellular cholesteryl ester storage pools are more than adequate $(2,4,11)$ in steroidogenic cells of aging rats.

Oxygen-derived free radicals and the accumulation of unrepaired oxidant-damaged cellular products have long been implicated in the aging process (15-19), and may, in fact, be responsible for some of the cellular changes described above. The risk of damage from lipid peroxidation is especially high for steroidogenic cells because the cells use molecular oxygen for steroid biosynthesis, and all interactions of the cellular cytochrome P450 enzymes with their lipid substrates and products (cholesterol and its metabolites) are major sources of free radical formation $(20,21)$. Indeed, in the rodent adrenal cortex, these lipid products, combined with the naturally high tissue content of unsaturated lipids, exaggerate the potential for cell damage and death from autooxidation events $(20,22,23)$. Because lipid peroxidation involving membranes can effect membrane structure and/or fluidity $(17-20,24)$, and virtually every event associated with cholesterol processing in steroidogenesis is dependent on the integrity of cell membranes $(25,26)$, the likelihood of steroidogenesis being adversely affected (especially the steps involving the transport of cholesterol) is quite high. Indeed, several earlier studies on various steroidogenic cells have suggested that hydrogen peroxide, an intermediate product of lipid peroxidation in cells, is capable of inhibiting steroidogenesis $(27-30)$, either by interfering with cholesterol transport to mitochondria, as in the case of cultured luteal cells (27), and/or by interfering with the action of P450 mitochondrial enzymes, as shown in studies of M-10 Leydig tumor cells and luteal cells $(29,30)$.

Mammalian cells are equipped with antioxidant systems to combat free radical damage $(17,22,24,31-34)$, and organs such as the adrenal appear to be particularly rich in these substances $(20,22)$. In general, the antioxidants consist of nonenzymatic substances, such as vitamins A, C, E, and other small molecular weight compounds such as glutathione $(17,22,24$, $31,32,34)$, and three basic enzymes, SOD, catalase (CAT), ${ }^{1}$ and glutathione peroxidases, especially selenium-dependent glutathione peroxidase (GPX) $(16,22,24,33)$. The fate of these various antioxidants in the adrenal of aging animals is not known.

The current study was designed to determine if a change in the efficiency of the adrenal antioxidant defense system in aging

1. Abbreviations used in this paper: CAT, catalase; FOX, ferrous oxidation-xylenol orange; FOXRS, FOX-reactive substances; GPX, glutathione peroxidase; GSH, reduced glutathione; GSSG, oxidized glutathione; TBARS, thiobarbituric acid-reactive substances; TPP, triphenylphosphine. 
rats is, in some way, associated with the age-associated decrease in adrenal steroidogenesis. The results suggest that this is the case. In young animals, the adrenal content of various nonenzymatic antioxidant substances is high compared with other tissues, as is the activity, protein, and mRNA for various important antioxidant enzymes. As the animals age, the levels of many of these protective substances decrease. These observations are consistent with the idea that aging in rats is associated with a deterioration of protective oxidative mechanisms, and in the adrenal these changes may lead to oxidative damage in membranes that are crucial for cholesterol processing and steroidogenesis.

\section{Methods}

\section{Materials}

[ $\left.\alpha{ }^{-32} \mathrm{P}\right] \mathrm{CTP}$ (sp act $29.6 \mathrm{TBq} / \mathrm{mmol} ; 800 \mathrm{Ci} / \mathrm{mmol}$ ) and $\left[\gamma-{ }^{32} \mathrm{P}\right] \mathrm{ATP}$ (sp act $222 \mathrm{TBq} / \mathrm{mmol} ; 6,000 \mathrm{Ci} / \mathrm{mmol}$ ) were obtained from DuPontNEN (Boston, MA). Various molecular biology-grade reagents were purchased from sources as listed in a previous publication (35). The ELISA reagents were purchased from Zymed Laboratories, Inc. (South San Francisco, CA). The following reagents came from Sigma Chemical Co. (St. Louis, MO): bovine liver catalase, bakers yeast glutathione reductase, bovine liver superoxide dismutase, milk xanthine oxidase, reduced $\beta$-nicotinamide adenine dinucleotide phosphate $(\beta \mathrm{NADPH})$, reduced glutathione (GSH), oxidized glutathione (GSSG), nitroblue tetrazolium, xanthine, bathocuproinedisulfonic acid, diethylenetraminepentaacetic acid (DETAPAC), xylenol orange, $\alpha$-tocopherol, ascorbic acid, and thiobarbituric acid.

Various antibodies and probes were generously provided by the following individuals: antibodies to bovine liver CuZn-SOD, human kidney Mn-SOD, and bovine liver catalase (36) from Dr. L. Oberley (University of Iowa, Iowa City, IA), and antibody against bovine GPX (37) from Dr. N. Rao (Doheny Eye Institute, Los Angeles, CA). These antibodies cross-react with antigens (proteins) from rodent sources (3639 ), including rat $(37,38)$. Also, Western blot analysis performed by us on adrenal tissue extracts further confirmed the specificity and cross species-reactivity of these antibodies. The full-length cDNA probes for rat liver CuZn-SOD (40) and Mn-SOD (41) were obtained from Dr. Y.-S. Ho (Wayne State University, Detroit, MI), a partial coding and spacer DNA fragment $(5.9 \mathrm{~kb})$ of rat $18 \mathrm{~S}$ ribosomal RNA (42) from Dr. D. M. Chikaraishi (Tufts University School of Medicine, Boston, MA), and a full-length cDNA probe for selenium-dependent rat GPX (43) from Dr. C. C. Reddy (Pennsylvania State University, University Park, PA).

\section{Animals}

Male Sprague-Dawley rats (Bantin and Kingman, Fremont, CA) were used for all studies. Young rats were obtained at 2 mo and used at 5 mo of age. Older virgin rats were obtained at 11-12 mo and maintained in our facility (2-5) up to 27 mo of age.

For vitamin $\mathrm{E}$ deficiency studies, rats were obtained at $3 \mathrm{wk}$ of age $(\sim 40-50 \mathrm{~g})$ and were randomly assigned to two treatment groups. Group A received a control diet (TD 88165) while group B received a diet totally deficient in vitamin E (TD 88163). Both diets were provided by Teklad Laboratories (Madison, WI). The rats were individually housed, fed ad libitum, and were used for experiments 6-7 mo after the onset of the dietary regimens.

In general, two pooled adrenals obtained from the same animal were used per experiment. All the experimental data with the exception of mRNA content were normalized either to per gram of wet weight of tissue or per milligram of protein. mRNA levels were expressed per unit of $18 \mathrm{~S}$ ribosomal RNA.

\section{Isolation of adrenocortical cells and in vitro steroidogenesis}

Freshly isolated adrenocortical cells $(1,2)$ from control and vitamin E-deficient rats were used to assay steroidogenesis. Triplicate cell sam- ples were incubated $\pm \mathrm{ACTH}(10 \mathrm{ng} / \mathrm{ml})$ or $\pm \mathrm{Bt}_{2} \mathrm{cAMP}(2.5 \mathrm{mM})$ at $37^{\circ} \mathrm{C}$ for $3 \mathrm{~h}$, and samples of incubation medium were assayed for corticosterone by direct radioimmunoassay as described previously ( 1 , 2). Results represent nanograms of corticosterone produced per microgram of DNA and are expressed as the mean \pm SE of duplicate determinations of four different adrenal cultures derived from four individual animals.

\section{Measurement of free radical damage}

Oxidative damage to tissue lipids (lipid peroxidation) was quantified by measuring lipid hydroperoxides and thiobarbituric acid-reactive substances (TBARSs). Oxidative damage to proteins was assessed by quantifying the carbonyl content of cellular proteins.

Determination of lipid peroxidation by measurement of lipid hydroperoxides. We employed the ferrous oxidation-xylenol orange (FOX) assay procedure of Nourooz-Zadeh et al. (44) for the direct measurement of lipid peroxides in tissue homogenates untreated or subjected to treatment with various prooxidants. In this method, hydroperoxides selectively oxidize ferrous ions to ferric ions in dilute acid, and the resultant ferric ions are assayed using a ferric-sensitive dye, xylenol orange, which selectively binds ferric ions to produce a colored (bluepurple) complex (extinction coefficient, $1.5 \times 10^{4} \mathrm{M}^{-1} \mathrm{~cm}^{-1}$ at 560 $\mathrm{nm}$; reference 44 ).

Freshly excised adrenal, liver, and other tissues were homogenized in buffer ( $0.15 \mathrm{M} \mathrm{KCl}, 5 \mathrm{mM}$ Tris maleate, $\mathrm{pH} 7.4$, and $1 \mathrm{mM}$ EDTA), and subsequently centrifuged at $800 \mathrm{~g}$ for $15 \mathrm{~min}$ to sediment the unbroken cells and nuclei. A total membrane fraction obtained by centrifugation of the supernatant at $105,000 \mathrm{~g}$ for $60 \mathrm{~min}$ was stored in liquid nitrogen until assayed for in vitro lipid peroxidation.

Lipid peroxidation occurring in the membrane fraction was examined directly or in the presence of $\mathrm{Fe}^{2+} / \mathrm{ADP} / \mathrm{NADPH}$ to assess enzymatic lipid peroxidation (45). The incubation mixture (mixture A) contained $50 \mathrm{mM}$ Tris $\mathrm{HCl} / 100 \mathrm{mM} \mathrm{KCl}, \mathrm{pH} 7.4$, membranes (equivalent to $10 \mathrm{mg}$ tissue) $\pm 50 \mu \mathrm{M} \mathrm{FeSO} / 1 \mathrm{mM} \mathrm{NADPH} / 5 \mathrm{mM}$ ADP After incubation at $37^{\circ} \mathrm{C}$ for $60 \mathrm{~min}, \mathrm{FOX}_{2}$ reagent (44) $\pm 1 \mathrm{mM}$ triphenylphosphine (TPP) was added and the absorbance of the resulting blue-purple color was read at $560 \mathrm{~nm}$. The concentration of hydroperoxides formed was calculated as total absorbancy minus absorbancy observed in the presence of TPP using an extinction coefficient of 1.5 $\times 10^{4} \mathrm{~m}^{-1} \mathrm{~cm}^{-1}$. TPP is used as a control for nonspecific (i.e., nonhydroperoxide-dependent) color formation. Note that $\mathrm{Fe}^{2+} /$ ascorbate was not used as prooxidant, because the presence of a high concentration of ascorbic acid in the assay mixture interferes with color development. Such interference from endogenous ascorbic acid is negligible, because washing procedures during membrane isolation completely remove soluble ascorbic acid (44).

Determination of lipid peroxidation by measurement of TBARS. Tissue susceptibility to lipid peroxidation was also assayed by measurement of TBARS in the membrane preparations according to the method of Pyles et al. (46). TBARS formation was determined under basal conditions (endogenous) and in the presence of $\mathrm{Fe}^{2+} / \mathrm{ADP} / \mathrm{NADPH}$ (enzymatic) (45) and $\mathrm{Fe}^{2+}$ /ascorbate (nonenzymatic) (45) as prooxidants. After incubation of tissues with mixture $A$ at $37^{\circ} \mathrm{C}$ for $60 \mathrm{~min}$, peroxidation development was terminated by the addition of TBA reagent containing butylated hydroxytoluene. The absorbances of organic fraction were simultaneously determined at 510,532 , and $560 \mathrm{~nm}$. The amount of 532-nm absorption resulting from TBARS (malondialdehyde, MDA equivalent) is calculated by the following equation (46), which uses an extinction coefficient of $1.56 \times 10^{15} \mathrm{~cm}^{-1}$ for MDA: $\mathrm{MDA}_{532}=1.22$ $\left[\left(\mathrm{A}_{532}\right)-(0.56)\left(\mathrm{A}_{510}\right)+(0.44)\left(\mathrm{A}_{560}\right)\right]$.

In some cases, HPLC procedure was used to separate physically the authentic (TBA) ${ }_{2}$-MDA adduct from other chromogens absorbing at $532 \mathrm{~nm}$. This procedure eliminates artifacts caused by the reaction of TBA with other cellular constituents to give different chromogens (47, 48). We employed a procedure modified from Draper et al. (47) for HPLC determination of TBARS using a $\mu$ Bondapack C18 column (Waters Associates, Milford, MA).

Determination of protein carbonyl content. Assay of carbonyl groups (aldehydes and ketones) in proteins provides a convenient tech- 
nique for detecting and quantifying oxidative modification of proteins $(18,49)$. In the current studies, protein carbonyls were determined according to the procedure of Reznick and Packer (49).

\section{Measurement of non enzymatic antioxidants}

Vitamin C (ascorbic acid). Total ascorbate (i.e., reduced and oxidized ascorbate) was quantified in the trichloroacetic acid (5\%) extracts of adrenals and other tissues by the colormetric procedure of Omaye et al. (50).

Vitamin $E$ ( $\alpha$-tocopherol). Tissue levels of vitamin $\mathrm{E}$ were determined by HPLC procedures (51) using a $\mu$ Bondapack C18 column.

The vitamin $\mathrm{E}$ content of adrenal and liver subcellular membranes, cytosol, and lipid droplets was determined as follows: adrenal and liver homogenates were centrifuged to provide nuclear $(800 \mathrm{~g}, 10 \mathrm{~min})$, mitochondrial $(5,000 \mathrm{~g}, 15 \mathrm{~min})$, and microsomal $(105,000 \mathrm{~g}, 60 \mathrm{~min})$ fractions. After each centrifugation, the distinct floating lipid droplet band was removed, resuspended in buffer, and saved. Aliquots of the pooled lipid droplet fractions, total homogenate, and subcellular fractions were extracted and quantified for cholesteryl esters (2) and $\alpha$ tocopherol. Each partially purified subcellular fraction showed 3-4-fold enrichment of specific marker enzymes $(2,3)$.

Glutathione. Total glutathione and oxidized glutathione (GSSG) was measured in acidic homogenate extracts by the method of Roberts and Francetic (52). Reduced glutathione (GSH) content was calculated as a difference of total glutathione minus oxidized glutathione. Results are expressed as nanomoles of GSH or GSSG per gram of tissue.

\section{Measurement of antioxidant enzyme activity}

For determination of enzymatic activity, adrenal and liver tissues were homogenized in buffer ( $50 \mathrm{mM}$ potassium phosphate buffer, $\mathrm{pH} 7.4$, $0.1 \mathrm{mM}$ EDTA), briefly sonicated, and centrifuged at $600 \mathrm{~g}$ for $10 \mathrm{~min}$ $(2,13)$; supernatant fractions were stored at $-90^{\circ} \mathrm{C}$ until assayed for various enzyme activities and protein $(2,13)$.

SOD assay. Total SOD was measured by the procedure of Spitz and Oberley (53). $2 \mathrm{mM} \mathrm{NaCN}$ was used to inhibit CuZn-SOD activity and measure Mn-SOD activity. CuZn-SOD activity was calculated from total activity minus activity observed in the presence of $2 \mathrm{mM} \mathrm{NaCN}$. One unit of SOD activity is defined as the amount of enzyme that inhibits the NBT reduction 50\% of maximum inhibition. Specific activity is expressed as units per milligram of protein.

CAT assay. CAT activity was measured according to the method of Aebi (54) with modifications (55). Specific activity is expressed as $\mathrm{k}$ units per milligram of protein (54).

GPX assay. Selenium-dependent GPX was measured by the method of Lawrence and Burk (56) using $\mathrm{H}_{2} \mathrm{O}_{2}, \mathrm{GSH}$, and NADPH as substrates. One unit of GPX activity is defined as the amount of enzyme that catalyzes the oxidation of $1 \mathrm{mmol}$ of NADPH per minute. Specific activity is expressed as units per minute per milligram of protein.

\section{Expression of antioxidant enzymes}

Mass of antioxidant enzymes. Enzyme-linked immunoabsorbent assays (ELISA) were performed according to Duckworth et al. (57). Adrenal and liver samples were homogenized in ice-cold buffer containing protease inhibitors (57) and were sonicated and centrifuged. Extracts were stored at $-90^{\circ} \mathrm{C}$ until assayed.

Adrenal and liver extracts $(0.5-2.5 \mu \mathrm{g})$ were absorbed to Immulon I ELISA plates (Dynatech, Chantilly, VA) in coating buffer $(0.1 \mathrm{M}$ carbonate-bicarbonate buffer, $\mathrm{pH} 9.6$ ) overnight at $4^{\circ} \mathrm{C}$. Endogenous peroxidase activity was blocked by pretreating the coated plates with $0.1 \%$ phenylhydrazine followed by $0.3 \% \mathrm{H}_{2} \mathrm{O}_{2}$ in methanol. Subsequently, plates were blocked by Blotto (5\% nonfat dry milk in Trisbuffered saline) overnight at $4^{\circ} \mathrm{C}$, washed with Tween-Tris-buffered saline (TTBS), and incubated with rabbit anti-CuZn-SOD, Mn-SOD, CAT, or GPX for $2-4 \mathrm{~h}$ at $37^{\circ} \mathrm{C}$. Finally, the plates were developed with goat anti-rabbit IgG conjugated with horseradish peroxidase and 3,3',5,5'-tetramethylbenzidine (TMB) liquid substrate system. The absorbance was read at $450 \mathrm{~nm}$ on a automatic microplate reader, and results are expressed as arbitrary absorbancy units $\times 10^{-3}$ per milligram of protein. All measurements were made using linear concentrations of tissue (protein) extracts.

Measurements of messenger RNA levels. The steady-state levels of CuZn-SOD, Mn-SOD, CAT, and GPX mRNAs were determined using a sensitive ribonuclease protection assay (RPA) as described previously (35). Because this technique requires only a small amount of cellular RNA, the levels of four types of mRNAs can be easily measured using total RNA obtained from two pooled adrenals of the same animal.

Molecular cloning of cDNA fragments. Cloned cDNA inserts for SODs, CAT, GPX, and 18S ribosomal RNA were subcloned into pBluescript $\mathrm{KS} \mathrm{II}^{+}\left(\mathrm{pBS} \mathrm{KSH}^{+}\right)$so that RNA complementary to the mRNA (antisense) could be synthesized using either T3 or T7 RNA polymerase. cDNA fragments were cloned into the polylinker region of the pBluescript $\mathrm{KSII}^{+}\left(\mathrm{PBS} \mathrm{KSII}^{+}\right.$) vector employing standard cloning techniques. For the CuZn-SOD probe, a 388-bp EcoRI-PstI fragment (position 277-664) was subcloned into EcoRI-PstI sites of pBS KSII ${ }^{+}$. For MnSOD a 265-bp PVUII-PVUII fragment (position 155-420) was cloned in the SmaI site of pBS KSII ${ }^{+}$. Similarly, a 533-bp EcoRI fragment (position 319-852) of GPX cDNA was subcloned into the EcoRI site of the pBS KSII ${ }^{+}$. Finally, a 268-bp fragment (position $1176-1423$ ) rat liver catalase (58) was obtained by reverse transcription-PCR of rat liver RNA and cloned into the HindIII-EcoRI sites of the PBS $\mathrm{KSII}^{+}$. Ligation of inserts and transformation of Escherichia coli strain XL1 Blue with the recombinant $\mathrm{pBS} \mathrm{KSII}{ }^{+}$plasmids was carried out following standard methods. Northern blotting analyses demonstrated that these cDNAs detect the specific message and do not crosshybridize to other irrelevant mRNA transcripts (data not shown).

Preparation of ${ }^{32} \mathrm{P}$-labeled riboprobes. Antisense ${ }^{32} \mathrm{P}$-labeled cRNA probes were synthesized using $\left[{ }^{32} \mathrm{P}\right] \mathrm{rCTP}$, lineraized plasmids (35), and appropriate T7 or T3 RNA polymerase following the method supplied in the Stratagene (La Jolla, CA) in vitro transcription kit.

Isolation and quantitation of mRNA. Total RNA from adrenal and liver tissues was isolated according to the procedure of Chomczynski and Sacchi (59). Aliquots of total RNA (10 $\mu \mathrm{g})$ or control tRNA (10 $\mu \mathrm{g}$ ) were hybridized with freshly synthesized antisense riboprobes for CuZn-SOD, Mn-SOD, CAT, GPX, or 18S ribosomal RNA transcripts and the RNA:RNA hybrids were digested with RNase A and T1 (35). The protected fragments were resolved by electrophoresis followed by autoradiography to visualize the bands and scanning densitometry for quantitation. Data were normalized to the $18 \mathrm{~S}$ ribosomal RNA signal (35).

In situ hybridization. Rat adrenals were either perfusion fixed with $4 \%$ paraformaldehyde ( $20 \mathrm{~min})$, excised, cut in half, and fixed for an additional $3 \mathrm{~h}$ before dehydration and paraffin embedment, or quick frozen in dry ice-chilled isopentane and stored at $-20^{\circ} \mathrm{C}$ until used. Sections from both types of blocks were cut at $8 \mu \mathrm{m}$ and placed on DEPC-water washed, polylysine-coated grids. Frozen sections were subsequently fixed for $20 \mathrm{~min}$ in $4 \%$ paraformaldehyde at room temperature. The protocol for the dewaxed or frozen sections was similar and followed the procedure of Watkins $(60)$. cRNA probes were ${ }^{35} \mathrm{~S}$-labeled antisense, ${ }^{35} \mathrm{~S}$-labeled sense, or ${ }^{35} \mathrm{~S}$-labeled antisense $+10 \times$ unlabeled antisense cRNA incubated with sections for $18 \mathrm{~h}$ at $55^{\circ} \mathrm{C}$. All pre-probe solutions were prepared with diethyl polycarbonate (DEPC) water. All post-probe equipment was kept separated from pre-probe steps in subsequent experiments. The radioautographs were exposed in light-tight boxes for 7-21 d at $4^{\circ} \mathrm{C}$, developed in D19, air dried, and stained lightly with hematoxylin and eosin.

Immunohistochemistry. Paraffin-embedded blocks used for in situ hybridization techniques were also sectioned at $6 \mu \mathrm{m}$, mounted on polylysine-coated slides, deparaffinized, blocked with $0.3 \% \mathrm{H}_{2} \mathrm{O}_{2}$ and $10 \%$ goat serum, and incubated with rabbit antibodies to human kidney $\mathrm{Mn}-$ SOD (36) or preimmune rabbit antisera $\left(1: 200,18 \mathrm{~h}, 4^{\circ} \mathrm{C}\right)$. Subsequently, the sections were washed, treated with goat anti-rabbit IgGperoxidase $(1: 200,30 \mathrm{~min})$ and freshly prepared diaminobenzidene (Zymed Laboratories) $+3 \% \mathrm{H}_{2} \mathrm{O}_{2}$ for $2-7 \mathrm{~min}$, depending on color development.

\section{Statistical analysis}

All results were expressed as the mean \pm SE unless stated otherwise. The Student's $t$ test or analysis of variance (ANOVA) was used to 
Table I. In Vitro Prooxidant-induced TBAR Formation in Tissue Homogenates of Young Rats

\begin{tabular}{lccc}
\hline & \multicolumn{3}{c}{ nmol MDA formed/mg protein/h } \\
\cline { 2 - 4 } Tissue homogenate & Basal & $\begin{array}{c}\text { Enzymatic } \\
\left(\mathrm{Fe}^{2+} / \mathrm{ADP} /\right. \\
\text { NADPH })\end{array}$ & $\begin{array}{c}\text { Nonenzymatic } \\
\left(\mathrm{Fe}^{2+} /\right. \\
\text { ascorbate })\end{array}$ \\
\hline Adrenal & $0.21 \pm 0.03$ & $1.18 \pm 0.16$ & $1.32 \pm 0.14$ \\
Brain & $7.69 \pm 1.19$ & $25.5 \pm 2.63$ & $15.43 \pm 1.81$ \\
Heart & $0.48 \pm 0.06$ & $3.17 \pm 0.58$ & $0.69 \pm 0.08$ \\
Kidney & $1.63 \pm 0.18$ & $25.61 \pm 3.81$ & $5.81 \pm 0.68$ \\
Liver & $0.97 \pm 0.11$ & $21.94 \pm 1.85$ & $15.28 \pm 1.61$ \\
Lung & $0.61 \pm 0.07$ & $2.12 \pm 0.27$ & $1.79 \pm 0.21$ \\
Skeletal muscle & $0.83 \pm 0.09$ & $4.05 \pm 0.43$ & $1.01 \pm 0.07$ \\
Spleen & $0.50 \pm 0.05$ & $0.68 \pm 0.08$ & $0.52 \pm 0.03$ \\
Testis & $3.01 \pm 0.41$ & $22.50 \pm 2.39$ & $8.89 \pm 1.06$ \\
& & &
\end{tabular}

Results are the means \pm SE of five separate experiments. MDA, malondialdehyde.

evaluate the differences of the means between groups. A $P$ value of $<0.05$ was considered significant.

\section{Results}

This study is divided into two parts. In part I, we examine young rats and compare various aspects of the oxidative defense system of adrenals with several other organs. In part II, we track changes in these same protective mechanisms as rats age.

\section{Young rats}

Endogeneous lipid peroxidation and susceptibility of various rat tissues to prooxidant-induced lipid peroxidation. Because no one assay measuring lipid peroxidation is entirely reliable (48), adrenal homogenate lipid peroxidation was measured as "basal" or "prooxidant-induced" levels using an endproduct assay (Table I TBARS) in which measurements were made colorimetrically (or by HPLC), or by a new sensitive method for measuring lipid peroxides based on the principle of peroxide-mediated oxidation of $\mathrm{Fe}^{2+}$ to $\mathrm{Fe}^{3+}$ under acidic conditions (Table II, FOXRS).

Table I indicates that of the eight organs tested, the adrenal

Table II. Formation of FOXRS (Lipid Peroxides) and TBARS in Adrenal and Liver Homogenates from Young Rats

\begin{tabular}{lcc}
\hline & $\begin{array}{c}\text { FOXRS } \\
\text { (nmol lipid peroxides } \\
\text { formed/mg protein/h) }\end{array}$ & $\begin{array}{c}\text { TBARS } \\
\text { (nmol MDA formed } \\
\text { formed/mg protein/h) }\end{array}$ \\
\hline $\begin{array}{l}\text { Adrenal } \\
\text { Basal } \\
\text { Enzymatic } \\
\quad\left(\mathrm{Fe}^{2+} / \mathrm{ADP} / \mathrm{NADPH}\right)\end{array}$ & $2.34 \pm 0.37$ & $0.20 \pm 0.04$ \\
$\begin{array}{l}\text { Liver } \\
\text { Basal } \\
\text { Enzymatic } \\
\quad\left(\mathrm{Fe}^{2+} / \mathrm{ADP} / \mathrm{NADPH}\right)\end{array}$ & $759.0 \pm 66$ & $1.29 \pm 0.15$ \\
\hline
\end{tabular}

Results are the means \pm SE of experimental data obtained from five separate experiments.
Table III. Vitamin C (Ascorbic Acid), Vitamin E ( $\alpha$-Tocopherol), and Glutathione (Reduced) Content in Tissues of Young Rats

\begin{tabular}{|c|c|c|c|}
\hline Tissue homogenate & $\begin{array}{l}\text { Vitamin C } \\
(\mathrm{nmol} / \mathrm{g} \\
\text { tissue } \pm \mathrm{SE})\end{array}$ & $\begin{array}{c}\text { Vitamin } \mathrm{E} \\
(\mathrm{nmol} / \mathrm{g} \text { tissue } \pm \mathrm{SE})\end{array}$ & $\begin{array}{c}\text { Glutathione } \\
\text { (reduced) } \\
\text { (nmol/g tissue } \pm \mathrm{SE} \text { ) }\end{array}$ \\
\hline Adrenal & $21,766 \pm 732$ & $481 \pm 42$ & $8,088 \pm 1325$ \\
\hline Brain & $2,378 \pm 57$ & $24 \pm 3$ & $1,863 \pm 257$ \\
\hline Heart & $318 \pm 17$ & $63 \pm 8$ & $919 \pm 179$ \\
\hline Kidney & $1,618 \pm 85$ & $28 \pm 4$ & $3,274 \pm 407$ \\
\hline Liver & $1,607 \pm 108$ & $39 \pm 7$ & $6,785 \pm 958$ \\
\hline Lung & $2,107 \pm 216$ & $42 \pm 8$ & $1,401 \pm 254$ \\
\hline Ovary (luteinized) & $5,440 \pm 278$ & $344 \pm 59$ & $4,785 \pm 358$ \\
\hline Ovary (regular) & $3,595 \pm 119$ & $161 \pm 26$ & $4,424 \pm 603$ \\
\hline Skeletal muscle & $57 \pm 6$ & $32 \pm 5$ & $730 \pm 147$ \\
\hline Spleen & $4,185 \pm 80$ & $62 \pm 12$ & $2,316 \pm 287$ \\
\hline
\end{tabular}

Results are the means $\pm \mathrm{SE}$ of experimental data obtained from six separate experiments.

is the most protected against oxidative damage as measured by the TBARS assay. This is the case whether endogenous (basal) tissue levels are measured, and is generally the case if the tissues have been exposed to enzymatic or nonenzymatic prooxidants. Table 2 compares TBARS measurements obtained in adrenal and liver with the FOXRS method. The tests provide similar information indicating that both basal lipid peroxide levels and prooxidant-induced formation of lipid peroxides are far less in adrenal tissue than in liver.

Comparison of endogenous and prooxidant-induced lipid peroxidation of adrenal tissues from rats fed standard or vitamin E-deficient chow. Colorimetric TBAR measurements were made on adrenal homogenates from rats maintained on control or vitamin E-deficient diets for $7 \mathrm{mo}$. Consistent with the data of Table II, adrenals from control animals show minimal endogenous (basal) malondialdehyde levels and display only a 10fold increase in malondialdehyde levels following either enzymatic or nonenzymatic prooxidant treatment. Adrenal tissues from similarly aged vitamin E-deficient rats were far less resistant to lipid peroxidation than that of the controls and showed ninefold higher basal levels and 33-fold higher malondialdehyde levels than controls following the use of prooxidants (data not shown). Cells from the vitamin E-deficient rats (which showed increased hydroperoxide formation) were also less efficient than cells from control animals in corticosterone production: i.e., maximal, cAMP-stimulated corticosterone production was 40$50 \%$ lower than that of control cells (data not shown).

Nonenzymatic antioxidant levels in various rat tissues. Table III provides data on tissue levels of vitamin C and E and reduced glutathione in 10 rat tissues. In each case, the adrenal levels exceeded those of any other tissue measured. Adrenal vitamin $\mathrm{C}$ values were fourfold higher than those of the luteinized ovary (a steroidogenic tissue that processes large quantities of cholesterol and its metabolites), sixfold higher than control ovary, and some 15-fold higher than liver. Adrenal and ovary vitamin E levels were 5-10-fold higher than other tissues. Although glutathione levels of the adrenal were higher than those of the other tissues measured, the differential between tissues with the highest and lowest glutathione concentrations was not as wide as those seen with vitamin $\mathrm{C}$ and $\mathrm{E}$.

Antioxidant enzymes in adrenal and liver tissues. Fig. 1 

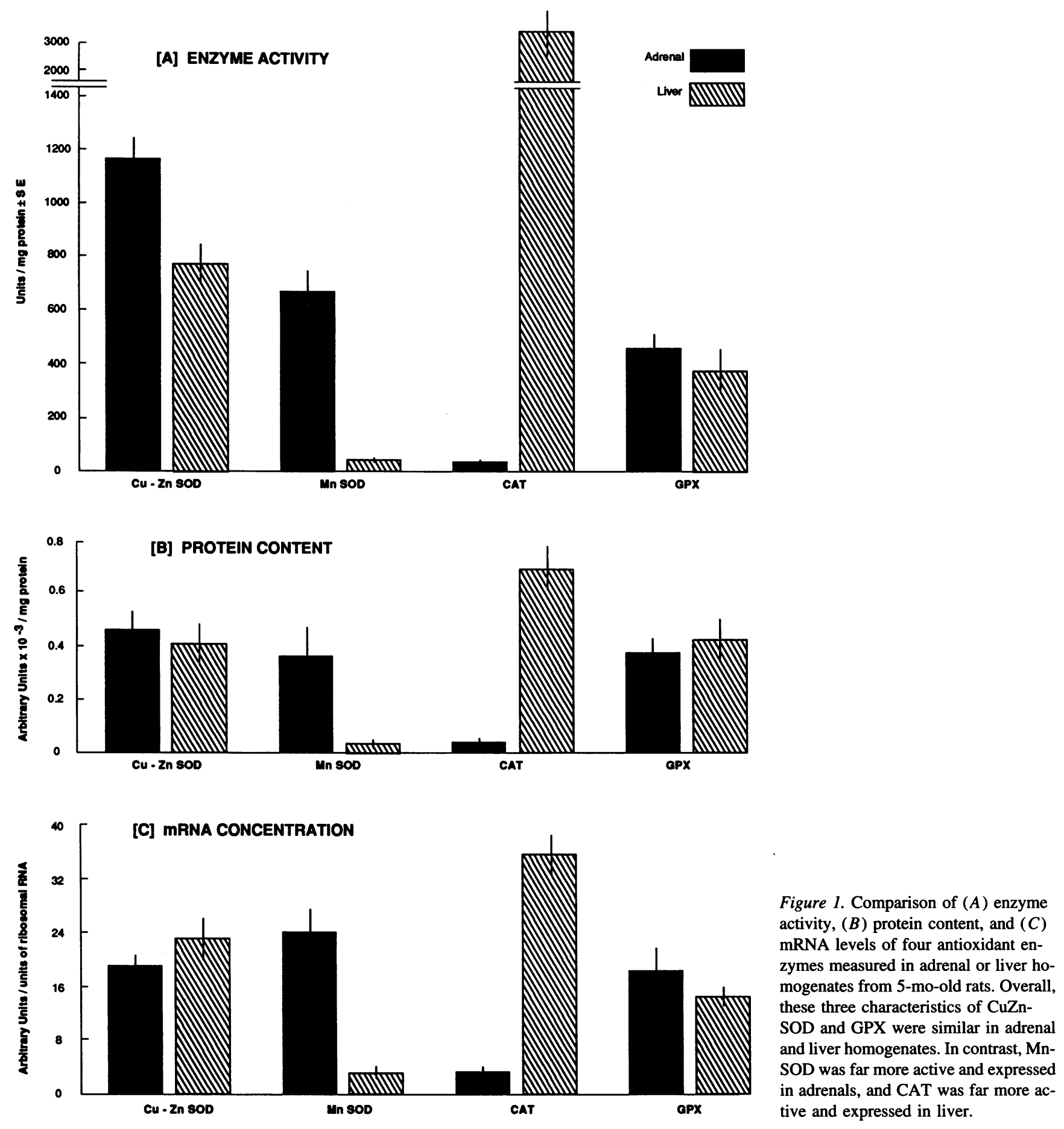

provides information on the enzyme activity (Fig. $1 A$ ), protein mass (Fig. $1 B$ ), and mRNA levels (Fig. $1 C$ ) of four different antioxidant enzymes, CuZn-SOD, Mn-SOD, CAT, and GPX, in adrenal and liver tissue obtained from young rats. CuZnSOD and Mn-SOD are enzymes that convert the superoxides formed in cells to $\mathrm{H}_{2} \mathrm{O}_{2}$; CuZn-SOD is the predominant form in mammalian cells located mainly in the cytosol of cells $(24$, 33 ), while Mn-SOD is primarily found in mitochondria (24, 33). CAT and GPX are enzymes that convert the intermediate, $\mathrm{H}_{2} \mathrm{O}_{2}$, to water; in addition, GPX plays a role in the metabolism of organic peroxides. The enzyme CAT is believed to be located in peroxisomes of the cell, whereas GPX is located in mitochondria and in the cell cytosol $(24,33)$.

Our results show that both SOD enzymes are especially active in adrenal homogenate (Fig. $1 \mathrm{~A}$ ), and that the activity of the mitochondrial form (Mn-SOD) is $\sim 12$ times higher in adrenal than in liver. This differential in adrenal and liver mitochondrial (Mn-SOD) activity may be explained by the fact that adrenal steroidogenesis relies on a constant flux of cholesterol and cholesterol/lipid products cycling through mitochondria $(25,26)$ (requiring protection against the accumulation of lipid peroxides), whereas hepatic mitochondria do not metabo- 


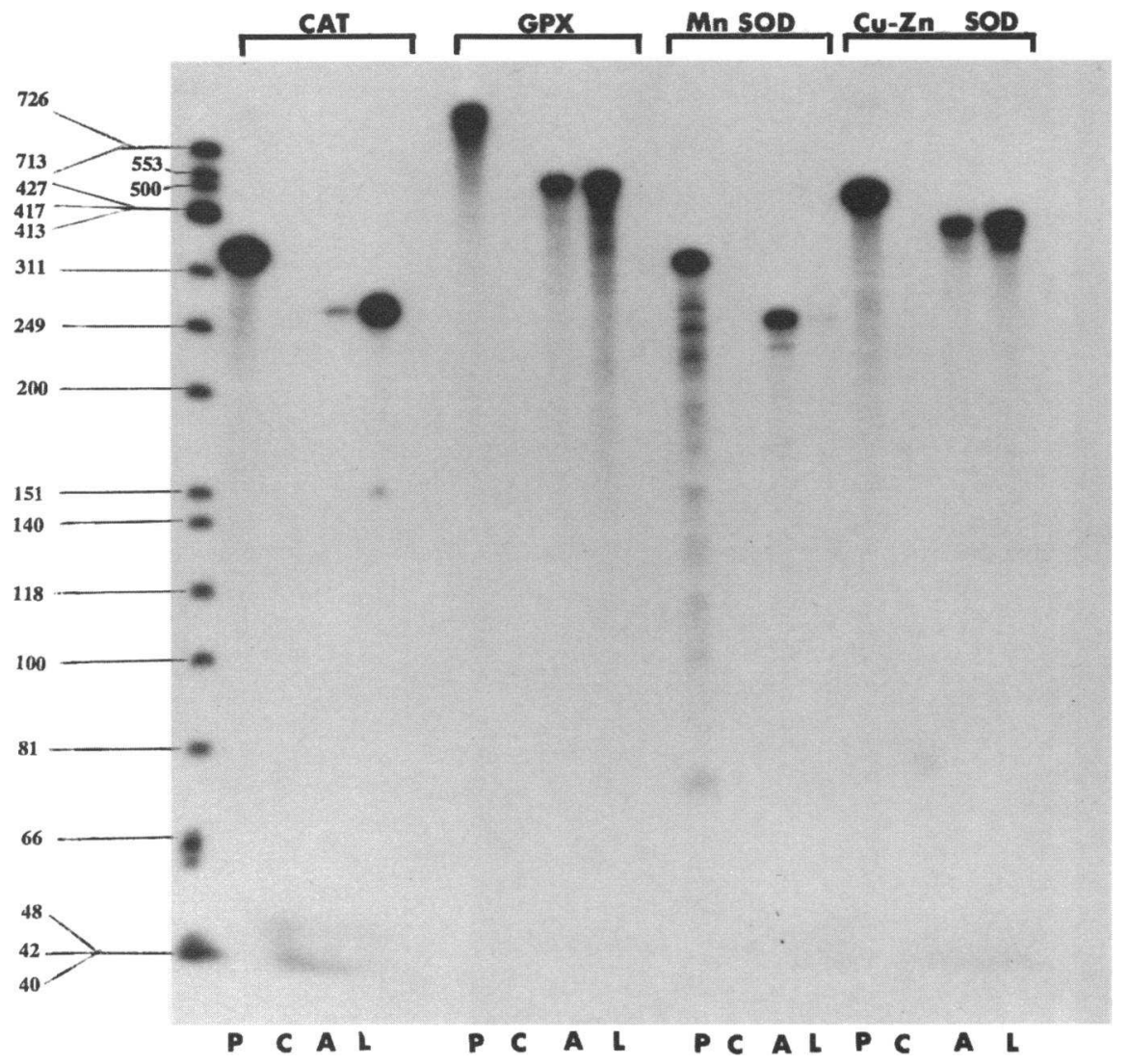

Figure 2. Autoradiogram from RNase protection assay for tissue CAT, GPX, Mn-SOD, and $\mathrm{CuZn-SOD.} \mathrm{Equal} \mathrm{amounts} \mathrm{of} \mathrm{total} \mathrm{RNA} \mathrm{from}$ liver or adrenal of 5-mo-old rats was hybridized with freshly synthesized antisense cRNA probe and the RNA:RNA hybrids were digested with RNAse $A$ and $t 1$. The protected fragments were resolved by electrophoresis followed by autoradiography. A, protected fragment from adrenal RNA; C, tRNA control; $L$, protected fragment from liver RNA; $P$, intact cRNA probe. Size markers in nucleotides (726-740) represent the size of the $\left[{ }^{32} \mathrm{P}\right]$ phosphorylated $\tau \mathrm{X} 174$ Hinf 1 digested fragments. lize lipids to any large extent and do not specifically require this protection. GPX also appears to be active in adrenal tissue (Fig. $1 A$ ); this is consistent with the notion that the enzyme is needed both in the cytosol and mitochondria to convert the $\mathrm{H}_{2} \mathrm{O}_{2}$ formed by the action of the two SOD enzymes. In contrast, CAT activity in adrenal homogenate (Fig. $1 A$ ) is barely measureable in comparison with that found in liver.

The protein mass (Fig. $1 B$ ) of the antioxidant enzymes in both adrenal and liver mirrors the measurements of enzyme activity seen in Fig. $1 A$; i.e., where enzyme activity is high or low, proteins levels are correspondingly high or low.

Likewise, mRNA values (Fig. $1 C$ ) for each enzyme (corrected for the ribosomal RNA from the same preparation) corresponds well with enzyme activity levels. Fig. 2 shows the data from RNase protection assays identifying protected mRNA fragments for CAT, GPX, Mn-SOD and CuZn-SOD; for each enzyme, lanes $1-4$ sequentially represent probe, tRNA control, and mRNA for adrenal and liver tissue extracts. Consistent with the enzyme activity and protein mass reported above, CuZnSOD, Mn-SOD, and GPX mRNA levels appear to be abundant in adrenal tissue extracts, while adrenal CAT mRNA is low.

In situ hybridization and immunocytochemistry of antioxidant enzymes. Experiments carried out with radioactive probes for Mn-SOD, CuZn-SOD, and GPX on sections of quick-frozen adrenals or paraformaldehyde-perfused/paraffin-embedded adrenals provide similar in situ hybridization data regarding the tissue mRNA distribution for the different antioxidant enzymes. Fig. 3 depicts the typical adrenal localization of mRNA for MnSOD indicating that exposed silver grains are to some extent present in cells of all layers of the adrenal cortex. Fewer grains appear associated with individual cells of the zona (Z.) glomerulosa than cells of $\mathrm{z}$. fasciculata (Fig. $3 C$ ), and fewer grains appear associated with cells of the adrenal medulla than $\mathrm{z}$. fasciculata cells (Fig. $3 \mathrm{D}$ ). No attempt was made to quantitate these impressions of grain density differences, because data on cell RNA concentration were not available for the different layers, and correction for mRNA values (as done in Fig. $1 C$ ) was not possible. Control in situ hybridization experiments carried out with excess (nonlabeled) probes showed a $>90 \%$ reduction in the hybridization signal obtained (compare Fig. 3, $A$ and $B$ ). Hybridization experiments carried out with CuZn-SOD or GPX probes showed the same tissue distribution as shown for MnSOD.

Immunohistochemistry studies suggest that all cortical layers of the rat adrenal show the presence of this enzyme, but the most peripheral layers of the $\mathrm{z}$. fasciculata and all layers of the z. reticularis appear heavily stained (data not shown).

\section{Aging rats}

In a previous study we described certain structural changes that occur in the adrenal of aging Spraque-Dawley rats (3). Of relevance to the current report is the fact that the mean adrenal weight of aged rats is substantially higher than that of young, mature (5-6-mo-old) rats, that the relative thickness of each zone within the adrenal cortex is similar in young and old rats, but that the cell size (specifically the size of corticosteroneproducing $\mathrm{z}$. fasciculata cells) of the older rat is larger than that of younger rats (3). To some extent, the larger cell size can be explained by the increased mass of accumulated lipid droplets in cells of the older animals $(2,3)$.

Effect of age on endogenous lipid peroxidation and susceptibility of adrenal tissue to prooxidant-induced lipid peroxidation. Table IV shows that adrenal homogenates from old (20-27mo-old) rats have $\sim$ twofold the endogenous levels of TBARS 

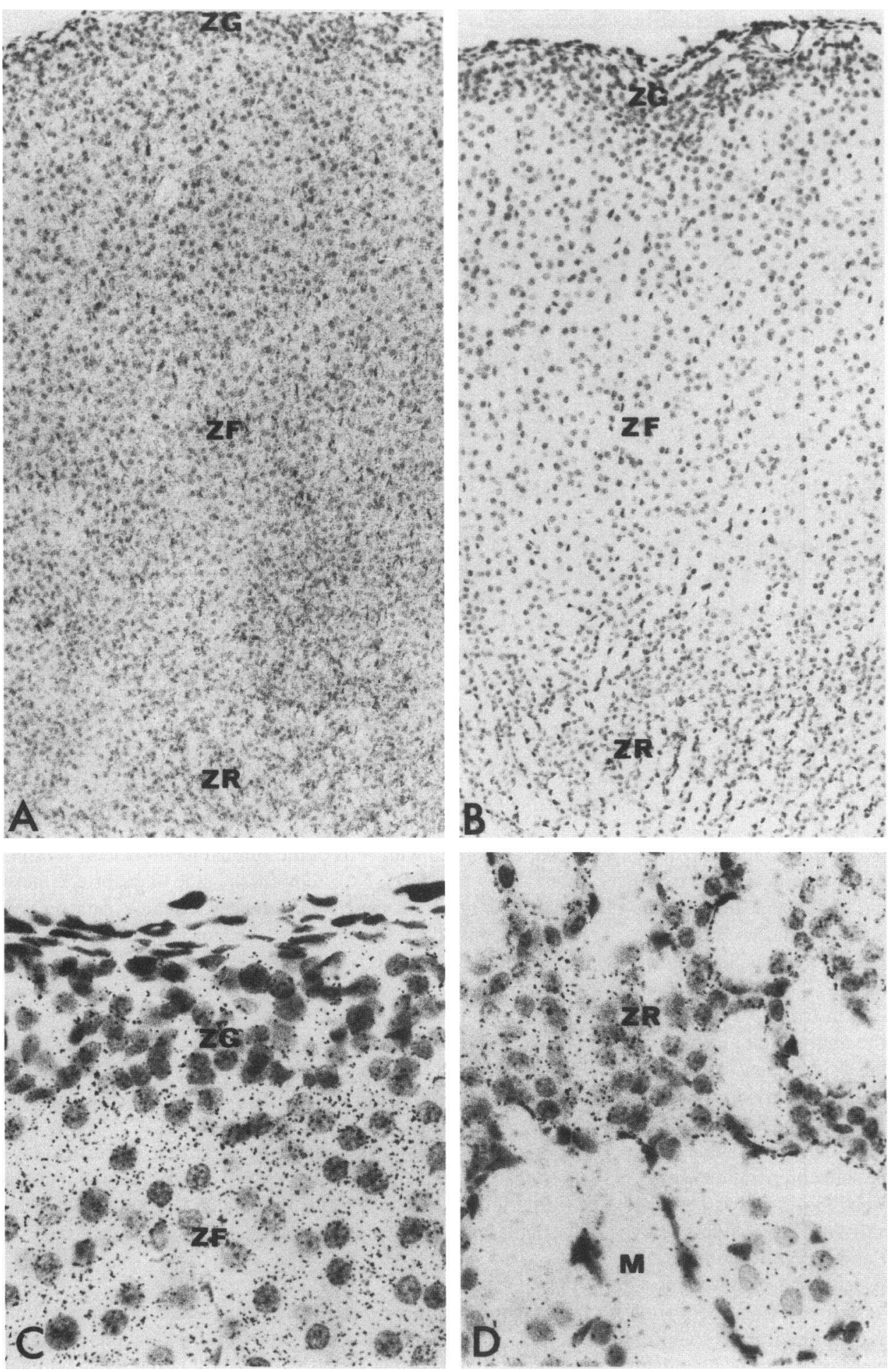

Figure 3. Representative autoradiographs of the in situ hybridization procedure utilizing a ${ }^{35} \mathrm{~S}$-labeled antisense Mn-SOD cRNA probe on sections of paraffin-embedded adrenal tissue of a young, 5-mo-old, rat. $(A)$ A low magnification micrograph $(\times 400)$ including cells from the z. glomerulosa (ZG), z. fasciculata (ZF), and z. reticularis (ZR). Exposed grains are visible throughout the cortical layers. $(B)$ A section (control) treated as in $A$, except the incubation mixture also contained 10 times excess unlabeled antisense probe. ( $C$ and $D$ ) A higher magnification view $(\times 1450)$ of an autoradiogram (as in $A$ ) in which it is possible to see individual exposed grains associated with cells of the different cortical zones and also medulla $(M)$. In general, such sections show the highest grain density to be associated with $\mathrm{ZF}$ and $\mathrm{ZR}$ layers. of young mature (5-mo-old) rats, regardless of method used. When the tissue homogenates are subjected to prooxidants, homogenates from the older animals are more susceptible to oxidation than homogenates from younger animals. Using the sensitive FOXRS technique for measuring lipid peroxides and dividing the animals into groups of increasing age, we obtain much the same information; i.e., as the animals age, adrenal tissue contains increasing amounts of endogenous lipid peroxides. Also, after prooxidant treatment, tissue from 2-year-old rats produce 5-6-fold the lipid peroxides formed by tissue of young mature rats, although, unlike the TBARS measurements, the ratio of induced lipid peroxide production over basal levels is about the same for each age group.

Effect of age on endogenous oxidized proteins in adrenal tissues. The carbonyl content of cellular proteins has previously been used as a measure of free radical-damaged protein in tissues such as liver $(18,49)$. In the current study, we find that protein damage in adrenal tissue is comparable with that found 
Table IV. Effect of Aging on the Formation of FOXRS and TBARS in Adrenal Homogenates

\begin{tabular}{cccc}
\hline Age (mo) & Basal & Enzymatic & Nonenzymatic \\
\hline $\begin{array}{c}\text { A. TBARS (colorimetric): } \\
\text { nmol MDA formed/ }\end{array}$ & & & \\
mg protein/h \pm SE & & & \\
5 & $0.18 \pm 0.04$ & $1.58 \pm 0.17$ & $1.68 \pm 0.15$ \\
$22-24$ & $0.46 \pm 0.07$ & $7.07 \pm 1.08$ & $7.74 \pm 1.12$ \\
B. TBARS (HPLC): nmol & & & \\
MDA formed/mg & & & \\
protein/h \pm SE & & & \\
5 & $0.071 \pm 0.009$ & $0.512 \pm 0.05$ & $0.51 \pm 0.04$ \\
$22-24$ & $0.231 \pm 0.035$ & $4.567 \pm 0.80$ & $4.29 \pm 0.64$ \\
C. FOXRS: nmol lipid & & & \\
peroxides formed/mg & & & \\
protein/h \pm SE & & & \\
2 & $1.98 \pm 0.21$ & $25.88 \pm 2.72$ & - \\
5 & $2.43 \pm 0.35$ & $29.25 \pm 2.50$ & - \\
12 & $5.32 \pm 0.45$ & $80.65 \pm 9.55$ & - \\
20 & $7.75 \pm 1.00$ & $124.00 \pm 16.30$ & - \\
24 & $10.48 \pm 1.25$ & $177.88 \pm 32.32$ & - \\
27 & $12.68 \pm 1.91$ & $163.88 \pm 24.35$ & - \\
& & & \\
\hline
\end{tabular}

Enzymatic prooxidant, $\mathrm{Fe}^{2+} / \mathrm{ADP} / \mathrm{NADPH}$; nonenzymatic prooxidant, $\mathrm{Fe}^{2+} /$ ascorbate. Results are the means $\pm \mathrm{SE}$ of experimental data obtained from three separate animals.

in liver $(1.59 \pm 0.15$ vs. $1.8 \pm 0.19 \mathrm{nmol} / \mathrm{mg}$ protein $\pm S E)$, and, in both tissues, aging increases the damage several fold (adrenal, $3.94 \pm 0.46$; liver, $6.43 \pm 0.17 \mathrm{nmol} / \mathrm{mg}$ protein ).

Effect of age on nonenzymatic antioxidant levels in adrenal tissues. Table $\mathrm{V}$ shows that endogenous levels of adrenal vita$\min \mathrm{C}$ and glutathione decrease with the age of the rat. The decline is greatest with vitamin $\mathrm{C}$, and the age-related difference is already statistically valid $(P<0.05)$ by $12 \mathrm{mo}$. With reduced glutathione, this level of significance does not develop until the animals reach 20 mo of age.

The situation with vitamin $\mathrm{E}$ is more complex. In the examination of total tissue homogenates, tissue vitamin $E$ levels actually increase with advancing age (young, $523 \mathrm{nmol} / \mathrm{g}$ tissue; old, $834 \mu \mathrm{mol} / \mathrm{g}$ tissue; $n=1$, obtained from four pooled adrenals from each group). However, when adrenal samples are subjected to subcellular fractionation and vitamin $E$ is measured in individual cell fractions, it appears that the stored lipid droplets of cells of older animals contain most $(\sim 60 \%)$ of the lipid soluble vitamin (as well as $85 \%$ of tissue cholesteryl ester), and that most of the other fractions (nuclear, mitochondrial, and microsomal) show relatively little change with age (data not shown).

Effect of age on antioxidant enzymes in adrenal tissues. CuZn-SOD, Mn-SOD, CAT, and GPX activity, protein content, and mRNA levels were measured in adrenal tissues from 5-moold young and 18-20-mo-old rats, and the results are shown in Fig. 4. With the exception of CAT, which shows little activity and no change with age, all the other antioxidant enzymes show a substantial decline in activity, protein content, and mRNA levels in the tissues obtained from the older animals. There is, in fact, a remarkable consistency in the data obtained from these three enzymes; in each case, aging is associated with a 3-4fold decline in enzyme activity (Fig. 4A), with a consistent but
Table V. Effect of Aging on Vitamin C (Ascorbic Acid), Vitamin E $(\alpha$-Tocopherol), and Glutathione Levels in Adrenal, Liver, and Plasma

\begin{tabular}{ccccc}
\hline Tissue & $\begin{array}{c}\text { Vitamin C } \\
(\mathrm{nmol} / \mathrm{g})\end{array}$ & $\begin{array}{c}\text { Vitamin E } \\
(\mathrm{nmol} / \mathrm{g})\end{array}$ & $\begin{array}{c}\text { GSH } \\
(\mathrm{nmol} / \mathrm{g})\end{array}$ & $\begin{array}{c}\text { GSSG } \\
(\mathrm{nmol} / \mathrm{g})\end{array}$ \\
\hline A. Adrenal & & & & \\
2 mo & $25,800 \pm 1710$ & $477 \pm 63$ & $8131 \pm 1467$ & $74.5 \pm 18.0$ \\
$5 \mathrm{mo}$ & $26,590 \pm 459$ & $651 \pm 62$ & $8701 \pm 1878$ & $88.5 \pm 25.1$ \\
$12 \mathrm{mo}$ & $21,260 \pm 1652^{*}$ & $730 \pm 79$ & $6866 \pm 1043$ & $99.0 \pm 29.2$ \\
$20 \mathrm{mo}$ & $15,390 \pm 827^{\ddagger}$ & $749 \pm 41$ & $5974 \pm 856^{*}$ & $11.1 \pm 26.6$ \\
$24 \mathrm{mo}$ & $11,550 \pm 284^{\ddagger}$ & $914 \pm 86^{*}$ & $5422 \pm 102^{*}$ & $89.0 \pm 20.2$ \\
$27 \mathrm{mo}$ & $10,670 \pm 775^{\ddagger}$ & $1003 \pm 114^{*}$ & $4181 \pm 622^{*}$ & $115.7 \pm 25.3$ \\
B. Liver & & & & \\
$2 \mathrm{mo}$ & $1477 \pm 87$ & $36.5 \pm 4.8$ & $6518 \pm 1261$ & $136 \pm 24$ \\
$5 \mathrm{mo}$ & $1556 \pm 86$ & $45.8 \pm 0.9$ & $6870 \pm 1497$ & $227 \pm 65$ \\
$12 \mathrm{mo}$ & $1074 \pm 62^{*}$ & $55.4 \pm 3.0^{*}$ & $7009 \pm 899$ & $163 \pm 10$ \\
$20 \mathrm{mo}$ & $815 \pm 71^{\ddagger}$ & $72.4 \pm 3.8^{\ddagger}$ & $5020 \pm 588$ & $155 \pm 33$ \\
$24 \mathrm{mo}$ & $743 \pm 65^{\ddagger}$ & $89.2 \pm 6.4^{\ddagger}$ & $4517 \pm 718^{*}$ & $150 \pm 20$ \\
$27 \mathrm{mo}$ & $741 \pm 58^{\ddagger}$ & $108.1 \pm 6.4^{\ddagger}$ & $3610 \pm 600^{*}$ & $155 \pm 21$ \\
C. Plasma & & & & \\
$2 \mathrm{mo}$ & $89.2 \pm 1.5$ & $15.5 \pm 1.4$ & - & - \\
$5 \mathrm{mo}$ & $90.9 \pm 3.3$ & $17.0 \pm 1.5$ & - & - \\
$12 \mathrm{mo}$ & $63.1 \pm 4.1^{\ddagger}$ & $18.5 \pm 0.7$ & - & - \\
$20 \mathrm{mo}$ & $55.6 \pm 6.0^{\ddagger}$ & $25.0 \pm 2.9$ & - & - \\
$24 \mathrm{mo}$ & $58.8 \pm 4.3^{\ddagger}$ & $28.8 \pm 4.8$ & - & - \\
$27 \mathrm{mo}$ & $46.1 \pm 6.8^{\ddagger}$ & $39.7 \pm 13.6$ & - & - \\
& & & &
\end{tabular}

Results are the means \pm SE of experimental data obtained from four separate experiments. ${ }^{*} P<0.05 ;{ }^{\ddagger} P 0.005$.

somewhat less impressive drop in levels of enzyme protein (Fig. $4 B$ ) and mRNA (Fig. $4 C$ ). Immunocytochemical and in situ hybridization techniques indicated that Mn-SOD protein and mRNA were distributed similarly in adrenal layers of 5- and 18-mo-old rats: i.e., the signal for this enzyme was most prominent in peripheral z. fasciculata layers and in cells of the $z$. reticularis (data not shown).

\section{Discussion}

The goal of this study was to determine whether an overall change in the antioxidant capacity of aging adrenocortical cells could account for their recognized decline in steroidogenic capacity. At the outset, we traced the changes in key adrenal tissue antioxidants (vitamins $\mathrm{E}$ and $\mathrm{C}$, glutathione, and the activity and genetic expression of various antioxidant enzymes) as rats aged from 2 to $24 \mathrm{mo}$. However, to understand the linkage between loss of antioxidant protection, aging, and steroidogenesis failure, it became necessary to document the fact that increasing free radical damage does occur in adrenal tissues over the life cycle of a rat, that the adrenal tissue of an aged rat is more susceptible to acute oxidative damage than is adrenal tissue from young animals, that dietary reduction of a key antioxidant (e.g., vitamin E), even in a young animal, results in enhanced oxidative damage to the tissue, and that this combination of factors is associated with a loss of adrenal steroidogenic function. The net result of these experiments has provided us with a comprehensive overview of various functional, biochemical, and molecular changes taking place as tissue autooxidation occurs with time, using age-related steroidogenic changes in rat adrenals as a model system. 


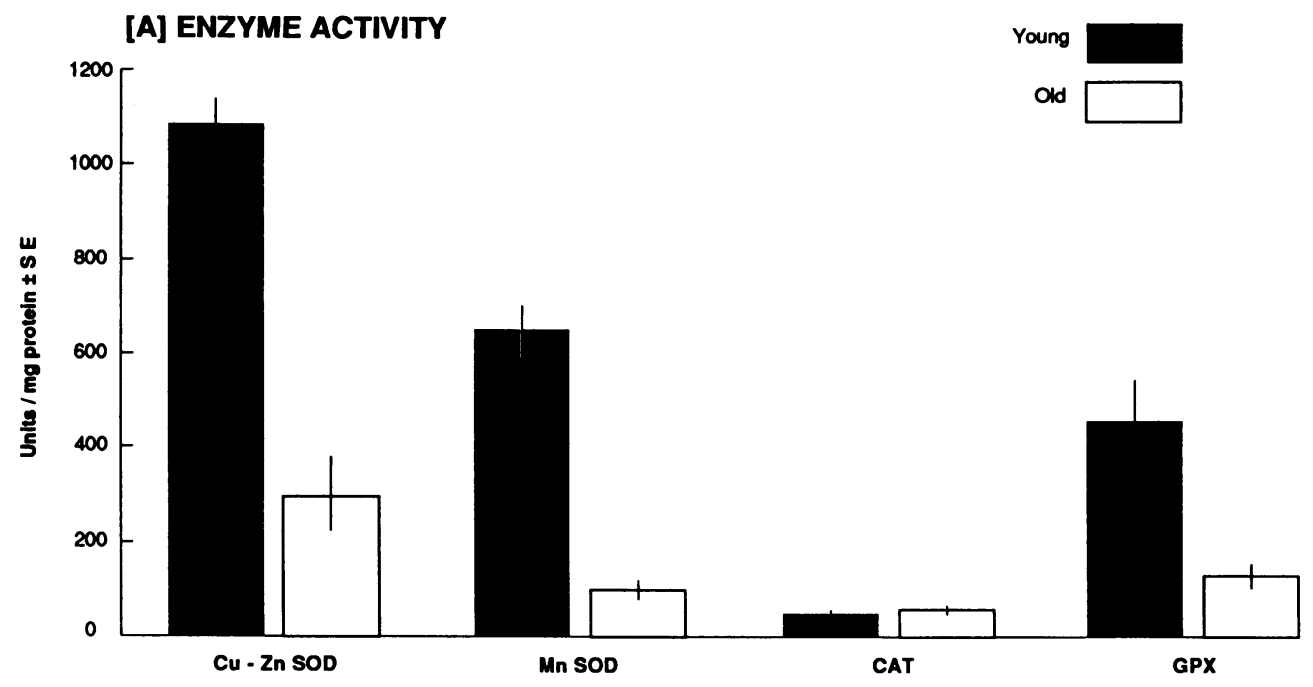

[B] PROTEIN CONTENT

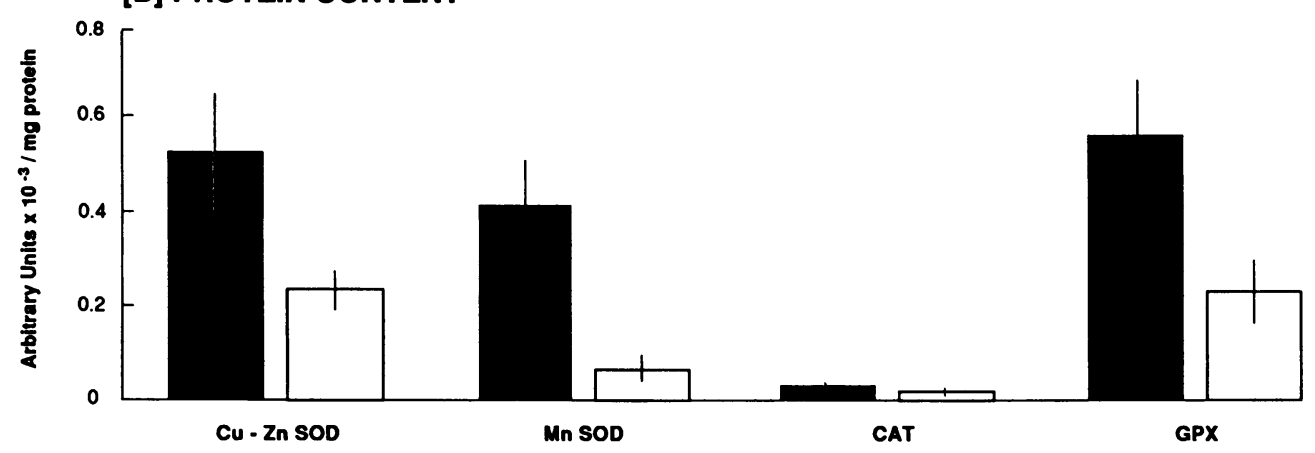

[C] MRNA CONCENTRATION

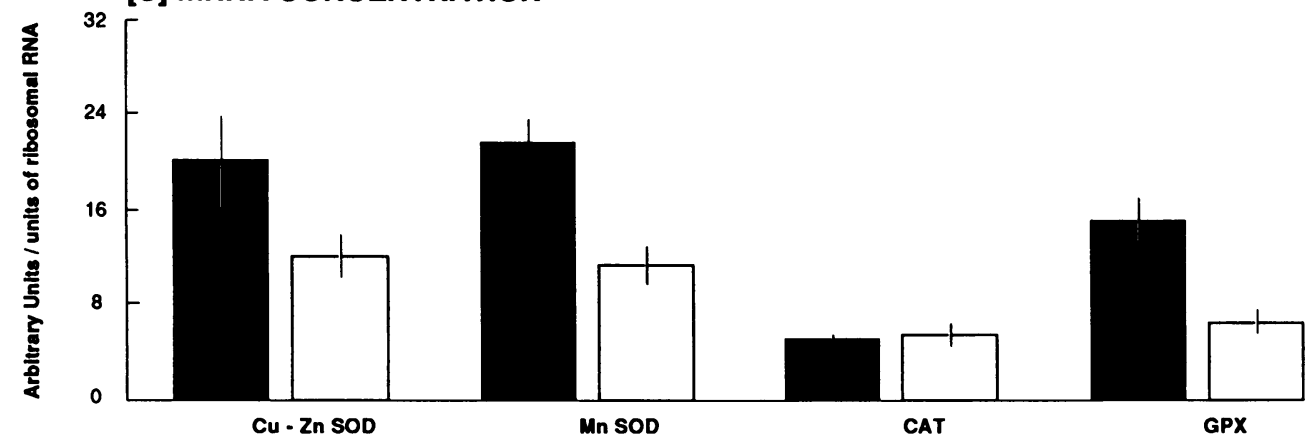

Figure 4. Comparison of $(A)$, enzyme activity, $(B)$ protein content, and $(C)$ mRNA concentrations of four different antioxidant enzymes in adrenal homogenates from young (5-moold) vs. old (18-20-mo-old) rats. With the exception of CAT, which is relatively unexpressed in adrenal tissue (see Fig. 1), the activity and expression of all other antioxidant enzymes was substantially decreased in the aging animals.
Overall, these data tell us that adrenals from young (2-5mo-old) animals are especially well protected against oxidative events. That is, among the various tissues tested, such adrenals display the least endogenous lipid peroxidation and the most resistance to prooxidant-induced lipid peroxidation, regardless of the assay method used. Not surprisingly, we found the adrenal tissues of young rats to contain exceedingly high concentrations of nonenzymatic antioxidants such as vitamins $\mathrm{C}$ and $\mathrm{E}$ and high levels of reduced glutathione compared with other tissues. Likewise, the activity and expression (mRNA and protein content) of adrenal antioxidant enzymes such as $\mathrm{Mn}-\mathrm{SOD}, \mathrm{CuZn}-$ SOD and GPX is high; Mn-SOD values are $\sim 10$-fold higher in adrenal than liver (such high enzyme activity is probably necessary to reduce mitochondrial lipid peroxidation products during steroidogenesis), and cytosolic CuZn-SOD and GPX levels in both adrenal and liver are substantial. Of the various enzymes measured, only adrenal CAT activity, mRNA, and protein levels are low compared with liver, and although the reason for this is not clear, it may simply reflect differences in the tissue content of peroxisomes in adrenal versus liver tissue; in any event, adrenal GPX levels are probably sufficient to remove the $\mathrm{H}_{2} \mathrm{O}_{2}$ generated by the tissue SODs. In situ hybridization experiments suggest that all layers of the adrenal are actively involved in making antioxidant enzymes. In general, sites of highest Mn-SOD synthetic activity and enzyme mass appear in the most peripheral $\mathrm{z}$. fasciculata and the most proximal z. reticularis regions.

In adrenal tissue from young rats maintained on a vitamin E-deficient diet for several months, the super-antioxidant defense system just described appears to have been undermined. 
There is a three-fold increase in TBARS and lipid peroxides in adrenal tissues of the vitamin E-deficient rats, and essentially no protection against prooxidant-induced damage. Predictably, adrenal vitamin $\mathrm{E}$ levels are one tenth control values. Also, hormone-stimulated, lipoprotein-supplied corticosterone production by isolated adrenocortical cells from such vitamin Edeficient rats decreases substantially compared with cells from identically aged rats fed normal rat chow. The latter finding is of importance in that it suggests a link between a decrease in steroidogenesis with increased levels of tissue lipid peroxidation and the loss of at least one of the defense mechanisms used by adrenal cells against oxidative damage.

The changes observed in adrenal tissue obtained from aging rats are remarkably similar to those described for the young rats fed a vitamin E-deficient diet. As the rats age from 5 to $27 \mathrm{mo}$, freshly isolated adrenal tissue shows increasing evidence of lipid peroxide formation and protein carbonyl content, suggesting that there has been an increase in oxidation of both lipids and proteins with age. This is seen with each of the methods used to detect such changes. Similarly, as the animals age, tissue levels of vitamin $\mathrm{C}$ and reduced glutathione progressively decrease. Perhaps the most significant change in aging rats, however, is that the activity and expression of each prominent adrenal antioxidant enzyme of the old rats decreases to less than half that found in adrenals of young mature rats.

The role of vitamin $\mathrm{E}$ during aging requires comment. Although total adrenal tissue vitamin $\mathrm{E}$ levels actually increase with age (as shown previously; reference 61 ), crude subcellular fractions from adrenal tissue indicate that more than $50 \%$ of tissue vitamin $\mathrm{E}$ is associated with lipid droplets, and because adrenal tissue from aging rats contains $\sim 50 \%$ more pooled lipid than adrenal tissue from young rats, there appears to be little net membrane change in vitamin $\mathrm{E}$ content with age. Whether this resistance to changes in vitamin $\mathrm{E}$ affords aging adrenocortical cells protection against more debilitating oxidative damage remains to be seen.

These results show that aging in Sprague-Dawley rats results in oxidative changes in adrenal tissue that appear linked to a reduction in efficiency of the normally protective antioxidant defense system. The timing of these changes in the life of the rat correlates generally with the age-related loss of corticosterone production in the same tissue $(1-3,5,14)$. Insofar as the decrease in hormone production in adrenal cells of aging animals is believed to result from the inefficient transport of intracellular cholesterol to mitochondria $(5,12)$, we speculate that all these events are causally related; i.e., the age-related reduction in oxidative defense mechanisms in adrenal tissue leads to oxidative damage of membrane or cytosolic factors important to cholesterol transport, and, as a consequence of this damage, cholesterol cannot reach appropriate mitochondrial side chain cleavage sites, and corticosterone production decreases.

This speculation (regarding the link between aging, alterations in antioxidant substances, tissue free radical damage, blockage of intracellular transport of cholesterol to mitochondria, and the idea that these sequential events cause the reduction in hormone synthesis) has an interesting biologic correlate in another aging steroidogenic model-the rat corpus luteum during luteolysis. Regression of the aging corpus luteum is an example of degeneration of a cellular function as a normal and necessary part of the reproductive cycle. Behrman and colleagues $(27,30)$ and others (28) have convincingly shown that luteinizing hormone (or use of the luteolysin, prostaglandin $F_{2 \alpha}$ ) causes the depletion of vitamin $\mathrm{C}$, an increase in superoxide and
$\mathrm{H}_{2} \mathrm{O}_{2}$ formation, and a block of hormone-sensitive cholesterol transport into the mitochondria of ovarian luteal cells. All this results in the reduction of progesterone formation by the luteal cells $(27,30)$ in a manner similar to that proposed in the present report for the reduction of corticosterone formation in the adrenals of aging rats.

Given these various observations, and the proposed function of antioxidant defense systems in preventing the cell damage that increasingly occurs with aging, one wonders why simple up-regulation of crucial antioxidant enzymes does not occur in aging. Of interest in this regard is recent evidence that oxidative damage during aging also may occur at the gene level $(16,24$, 62-65). Were this to occur in adrenal tissue, an initial insult at the DNA level $(62,64)$ could lead secondarily to the types of changes observed in this study. Ongoing studies from this laboratory are examining this possibility further.

\section{Acknowledgments}

This research was supported by the Research Services of the Department of Veterans Affairs.

\section{References}

1. Popplewell, P. Y., M. Tsubokawa, J. Ramachandran, and S. Azhar. 1986. Differential effects of aging on adrenocorticotropin receptors, adenosine 3 ', 5'monophosphate response, and corticosterone secretion in adrenocortical cells from Sprague-Dawley rats. Endocrinology. 119:2206-2213.

2. Popplewell, P. Y., and S. Azhar. 1987. Effects of aging on cholesterol content and cholesterol metabolizing enzymes in the rat adrenal gland. Endocrinology, 121:64-73.

3. Reaven, E., M. Kostrna, J. Ramachandran, and S. Azhar. 1988. Structural and function changes in rat adrenal glands during aging. Am. J. Physiol. 255:E903-E911.

4. Liao, C., E. Reaven, and S. Azhar. 1993. Age-related decline in the steroidogenic capacity of isolated rat Leydig cells: a defect in cholesterol mobilization and processing. J. Steroid Biochem. Mol. Biol. 46:39-47.

5. Azhar, S., and E. Reaven. 1994. Effect of age on cholesterol uptake and utilization by rat adrenals. I. Internalization of lipoprotein-derived cholesteryl esters. Mech. Ageing Dev. 77:13-25.

6. Lin, T., E. Murono, J. Osterman, D. O. Allen, and H. R. Nankin. 1980. The aging Leydig cells. I. Testosterone and adenosine 3', 5'-monophosphate responses to gonadotropin stimulation in rats. Steroids. 35:653-663.

7. Betheca, C. L., and R. F. Walker. 1979. Age-related changes in reproductive hormones and in Leydig cell responsivity in the male Fischer 344 rat. J. Gerontol. 34:21-27.

8. Malamed, S., and R. V. Carsia. 1983. Aging of the rat adrenocortical cell: response to ACTH and cyclic AMP in vitro. J. Gerontol. 38:130-136.

9. Tsitouras, P. D., M. A. Kowatch, and M. Harman. 1979. Age-related alterations of isolated rat Leydig cell function: gonadotropin receptors, adenosine 3', $5 '$-monophosphate response, and testosterone secretion. Endocrinology. 105:1400-1405.

10. Cheng, B., I. Horst, S. L. Mader, and J. Kowal. 1990. Diminished adrenal steroidogenic activity in aging rats: new evidence from adrenal cells cultured from young and aged normal and hypoxic animals. Mol. Cell. Endocrinol. 73:R7R12.

11. Rebuffat, P., A. S. Belloni, S. Rocco, P. G. Andreis, G. Neri, L. K. Malendowicz, G. Gottardo, G. Mozzocchi, and G. G. Nussdorfer. 1992. The effects of ageing on the zonae fasciculata and reticularis of the rat adrenal cortex. Cell Tissue Res. 270:265-272.

12. Markowska, A., P. Rebuffat, G. Gottardo, and G. G. Nussdorfer. 1994. Age-dependent changes in the function and morphology of mitochondria of rat adrenal zona fasciculata. Histol. Histopathol. 9:263-268.

13. Popplewell, P. Y., J. Butte, and S. Azhar. 1987. The influence of age on steroidogenic enzyme activities of the rat adrenal gland: enhanced expression of cholesterol side chain cleavage activity. Endocrinology. 120:2521-2528.

14. Reaven, E., L. Cao, and S. Azhar. 1994. Effect of age on cholesterol uptake and utilization by rat adrenals. II. Lipoproteins from young and old rats. Mech. Ageing Dev. 77:27-41.

15. Harman, D. 1956. Ageing: a theory based on free radical and radiation chemistry. J. Gerontol. 11:298-300.

16. Pacifici, R. E., and K. J. A. Davies. 1991. Protein, lipid and DNA repair systems in oxidative stress. The free-radical theory of aging revisited. Gerontology. 37:166-180. 
17. Stadtman, E. R. 1992. Protein oxidation and aging. Science (Wash. DC). 257:1220-1224.

18. Nohl, H. 1993. Involvement of free radicals in ageing: a consequence or cause of senescence. Br. Med. Bull. 49:653-667.

19. Shigenaga, M. K., T. M. Hagen, and B. N. Ames. 1994. Oxidative damage and mitochondrial decay in aging. Proc. Natl. Acad. Sci. USA. 91:10771-10778.

20. Hornsby, P. J., and J. F. Crivello. 1983. The role of lipid peroxidation and biological antioxidant in the function of the adrenal cortex. Part 2. Mol. Cell. Endocrinol. 30:123-147.

21. Hornsby, P. J. 1989. Steroid and xenobiotic effects on the adrenal cortex: mediation by oxidative and other mechanisms. Free Radical Biol. Med. 6:103115

22. Hornsby, P. J., and J. F. Crivello. 1983. The role of lipid peroxidation and biological antioxidant in the function of the adrenal cortex. Part I: background review. Mol. Cell. Endocrinol. 30:1-20.

23. Cheng, B., and J. Kowal. 1994. Analysis of adrenal cholesteryl esters by reversed phase high performance liquid chromatography. J. Lipid Res. 35:11151121.

24. Yu, B. P. 1994. Cellular defenses against damage from reactive oxygen species. Physiol. Rev. 74:139-162.

25. Jefcoate, C. R., B. C. Monamara, I. Artemenko, and T. Yamazaki. 1992. Regulation of cholesterol movement to mitochondrial cytochrome $\mathrm{P}^{4} \mathrm{sc}_{\mathrm{scc}}$ in steroid hormone synthesis. J. Steroid Biochem. Mol. Biol. 43:751-767.

26. Liscum, L., and N. K. Dahl. 1992. Intracellular cholesterol transport. $J$. Lipid Res. 33:1239-1254.

27. Behrman, H. R., and R. F. Aten. 1991. Evidence that hydrogen peroxide blocks hormone sensitive cholesterol transport into mitochondria of rat luteal cells. Endocrinology. 128:2958-2966.

28. Carlson, J. C., X. M. Wu, and M. Sawada. 1993. Oxygen radicals and the control of ovarian corpus luteum function. Free Radical Biol. Med. 14:79-84.

29. Stocco, D. M., J. Wells, and B. J. Clark. 1993. The effects of hydrogen peroxide on steroidogenesis in mouse Leydig tumor cells. Endocrinology. 133:2827-2832.

30. Musicki, B., R. F. Aten, and H. R. Behrman. 1994. Inhibition of protein synthesis and hormone-sensitive steroidogenesis in response to hydrogen peroxide in rat luteal cells. Endocrinology. 134:588-595.

31. Burton, G. W., and M. G. Traber. 1990. Vitamin E: antioxidant activity, biokinetics, and bioavailability. Annu. Rev. Nutr. 10:357-382.

32. DiMascio, P., M. E. Murphy, and H. Sies. 1991. Antioxidant defense systems: the role of carotenoids, tocopherols and thiols. Am. J. Clin. Nutr. 53:194S-200S.

33. Harris, E. D. 1992. Regulation of antioxidant enzymes. FASEB (Fed. Am. Soc. Exp. Biol.) J. 6:2675-2683.

34. Beyer, R. E. 1994. The role of ascorbate in antioxidant protection of biomembranes: interaction with Vitamin $\mathrm{E}$ and coenzyme Q. J. Bioenerg. Biomembr. 26:349-358.

35. Reaven, E., L. Tsai, M. Spicher, L. Shilo, M. Philip, A. D. Cooper, and S. Azhar. 1994. Enhanced expression of granulosa cell low density lipoprotein receptor activity in response to in vitro cell culture conditions. J. Cell. Physiol. 161:449-462.

36. Spitz, D. R., J. H. Elwell, Y. Sun, L. W. Oberley, T. D. Oberley, S. J. Sullivan, and R. J. Roberts. 1990. Oxygen toxicity in control and $\mathrm{H}_{2} \mathrm{O}_{2}$-resistant Chinese hamster fibroblast cell lines. Arch. Biochem. Biophys. 279:249-260.

37. Atalla, L. R., A. Sevanian, and N. A. Rao. 1988. Immunohistochemical localization of glutathione peroxidase in ocular tissue. Curr. Eye Res. 6:11811187.

38. Coursin, D. B., H. P. Cihla, T. D. Oberley, and L. W. Oberley. 1992 Immunolocalization of antioxidant enzymes and isozymes of glutathione $S$-transferase in normal rat lung. Am. J. Physiol. 263:L679-691.

39. Sun, Y., N. H. Colburn, and L. W. Oberley. 1993. Decreased expression of manganese superoxide dismutase mRNA and protein after immortalization and transformation of mouse liver cells. Oncol. Res. 5:127-132.

40. Ho, Y. -S., and J. D. Crapo. 1987. cDNA and deduced amino acid sequence of rat copper-zinc-containing superoxide dismutase. Nucleic Acids Res. 15:6746.

41. Ho, Y. -S., and J. D. Crapo. 1987. Nucleotide sequences of cDNAs coding for rat manganese-containing superoxide dismutase. Nucleic Acids Res. 15:10070

42. Chikaraishi, D. M., L. Buchanan, K. J. Danna, and C. A. Harrington. 1983. Genomic organization of rat rDNA. Nucleic Acids Res. 11:6437-6452.

43. Reddy, A. P., B. L. Hsu, P. S. Reddy, N. Li, K. Thyagaraju, C. C. Reddy,
M. F. Tam, and C. -P. D. Tu. 1988. Expression of glutathione peroxidase I gene in selenium-deficient rats. Nucleic Acids Res. 16:5557-5568.

44. Nourooz-Zadeh, J., J. Tajaddini-Sarmadi, and S. P. Wolff. 1994. Measurement of plasma hydroperoxide concentrations by the ferrous oxidation-xylenol orange assay in conjunction with triphenylphosphine. Anal. Biochem. 220:403409.

45. Slater, T. F., and K. H. Cheeseman. 1987. Lipid peroxidation. In Prostaglandins and Related Substances: A Practical Approach. C. Benedetto, R. G. McDonald-Gibson, S. Nigam, and T. F. Slater, editors. IRL Press, Washington, DC. $243-258$.

46. Pyles, L. A., E. J. Stejskal, and S. Einzig. 1993. Spectrophotometric measurement of plasma 2-thiobarbituric acid-reactive substances in the presence of hemoglobin and bilirubin interference. Proc. Soc. Exp. Biol. Med. 202:407419.

47. Draper, H. H., E. J. Squires, H. Mahmoddi, J. Wu, S. Agarwal, and M. Hadley. 1993. A comparative evaluation of thiobarbituric acid methods for the determination of malondialdehyde in biological materials. Free Radical Biol. Med. $15: 353-363$.

48. Gutteridge, J. M. C., and B. Halliwell. 1990. The measurement and mechanism of lipid peroxidation in biological systems. Trends Biochem. Sci. 15:129135.

49. Reznick, A. Z., and L. Packer. 1994. Oxidative damage to proteins: spectrophotometric method for carbonyl assay. Methods Enzymol. 233:357-363.

50. Omaye, S. T., J. D. Turnbull, and H. E. Sauberlich. 1979. Selected methods for the determination of ascorbic acid in animal cells, tissues and fluids. Methods Enzymol. 62:3-11.

51. Driskell, W. J., J. W. Neese, C. C. Bryant, and M. M. Bashor. 1982. Measurement of vitamin A and vitamin $\mathrm{E}$ in human serum by high-performance liquid chromatography. J. Chromatogr. 231:439-444.

52. Roberts, J. C., and D. J. Francetic. 1993. The importance of sample preparation and storage in glutathione analysis. Anal. Biochem. 211:183-187.

53. Spitz, D. R., and L. W. Oberley. 1989. An assay for superoxide dismutase activity in mammalian tissue homogenates. Anal. Biochem. 179:8-18.

54. Aebi, H. 1984. Catalase in vitro. Methods Enzymol. 105:121-127.

55. Ji, L. L., W. Stratman, and H. A. Lardy. 1988. Antioxidant enzyme systems in rat liver and skeletal muscle: influences of selenium deficiency, chronic training and acute exercise. Arch. Biochem. Biophys. 263:150-160.

56. Lawrence, R. A., and R. F. Burk. 1978. Species, tissue and subcellular distribution of non se-dependent glutathione peroxidase activity. J. Nutr. 108:211-215.

57. Duckworth, P. F., R. Vlahcevic, E. J. Studer, E. C. Gurley, D. M. Heuman Z. H. Beg, and P. B. Hylemons. 1991. Effect of hydrophobic bile acids on 3hydroxy-3-methylglutaryl coenzyme A reductase activity and mRNA levels in the rat. J. Biol. Chem. 266:9413-9418.

58. Furuta, S., H. Hayash, M. Hijikata, S. Miyazawa, T. Osumi, and T. Hashimoto. 1986. Complete nucleotide sequence of cDNA and deduced amino acid sequence of rat liver catalase. Proc. Natl. Acad. Sci. USA. 83:313-317.

59. Chomczynski, P., and N. Sacchi. 1987. Single-step method of RNA isolation by acid guanidinium thiocyanate-phenol-chloraform extraction. Anal. Biochem. 162:156-159.

60. Watkins, S. 1994. In situ hybridization and immunocytochemistry. In Current Protocols in Molecular Biology. F. M. Ausubel, R. Brent, R. E. Kingston D. D. Moore, J. G. Seidman, J. A. Smith, and K. Struhl, editors. John Wiley and Sons, New York. 14.0.1-14.6.13.

61. Weglicki, W. B., Z. Luna, and P. P. Nair. 1969. Sex and tissue specific differences in concentrations of a-tocopherol in mature and senescent rats. Nature (Lond.). 221:185-186.

62. Holmes, G. E., C. Bernstein, and H. Bernstein. 1992. Oxidative and other DNA damages as the basis of aging: a review. Mutation Res. 275:305-315.

63. Fawcett, T. W., S. L. Sylvester, K. D. Sarge, R. I. Moritmoto, and N. J. Holbrook. 1994. Effects of neurohormonal stress and aging on the activation of mammalian heat shock factor 1. J. Biol. Chem. 269:32272-32278.

64. Higami, Y., I. Shimokawa, T. Okimoto, and T. Ikeda. 1994. An agerelated increase in the basal level of DNA damage and DNA vulnerability to oxygen radicals in the individual hepatocytes of male F344 rats. Mutation Res. 316:59-67.

65. Supakar, P. C., M. H. Jung, C. S. Song, B. Chatterjee, and A. K. Roy 1995. Nuclear factor KB functions as a negative regulator for the rat androgen receptor gene and NF-KB activity increases during the age-dependent desensitization of the liver. J. Biol. Chem. 270:837-842. 